\title{
COLLECTIVE AGREEMENT - A TOOL FOR STRENGTHENING PUBLIC POLICIES IN THE AREA OF SOCIAL RESPONSIBILITY
}

\author{
Florian MARIN \\ The Bucharest University of Economic Studies, Bucharest, Romania \\ marinflorian_21@yahoo.com
}

\begin{abstract}
The article aims to identify and demonstrate the benefits of other tools besides those already in place, tools that ensure greater responsibility for companies, namely tools to ensure the transition of production flows towards a sustainable approach. The research method included entities representing the interest of the capital and labor determiners, in order to identify their organizational structure and concrete elements deriving from this relationship. The collection of data was based on the analysis of 52 collective agreements in force, which involved the identification of the synergy with the ISO 26000 principles. The data processing involved the organization and classification of the collective agreement clauses based on the ISO 26000 principles, following an individual analysis approach aimed to identify the synergy and compliance of the collective agreements with the ISO 26000 principles. The research highlighted a way of organizing at the level of the social partners fully adapted to the amplitude and characteristics of the environmental and social protection issues. Moreover, their work provides a concrete framework of commitments, expressed in a specific type of contract, namely the collective agreement. The latter integrates in a meaningful way the specific principles of ISO 26000, the situation that provides the collective bargaining institution as a solution to the need to make companies accountable, among others, for catalyzing the process of converting the transfer of the production flows towards the bioeconomic area. A collective agreement is a solution that does not involve the state intervention, it is immediate, and attracts binding commitments from companies to strengthen bioeconomy and social responsibility.
\end{abstract}

Keywords: collective agreement, social partners, corporate social responsibility, bioeconomy, ISO 26000.

\section{INTRODUCTION}

Capitalism is currently undergoing a significant ideological reorientation - a situation that can easily be noticed in the changes made to its operating systems. Clearly, this situation is a consequence of globalization and its effects, directly linked to the crises of the past 10 years, namely the crisis of migration and the financial crisis. This situation is also due to a difference in dynamics at the level of factors of production and the inability of certain factors of production to organize themselves and adapt to the dynamics imposed by technological progress. Technological progress, the internet or digitization are just some of the elements that have provided a good framework for capital and also significant mobility. If investments can be easily transferred from one continent to another, the same cannot be said about the 
labour factor, namely the labour force or the natural environment. This created an imbalance that exerts pressure on the capital. The capital must be made responsible for integrating into its activity the whole range of imperative variables necessary for a healthy social climate. The organizational capacity and the ability of the capital to organize itself, the structure of the capitalist economy and globalization have ensured the positioning of the capital interest in the forefront. All this adds to the dynamics of the social contracts and consumer behaviour, and they are also responsible for the increasingly aggressive behaviour that capital has manifested. Another important aspect raised in this context is generated by the growing population of the planet and the increase of the life span due to progress in the field of medicine. Consumption has increased significantly due to the increase in the number of consumers, along with the consumption of raw materials and materials used in the production process, a situation managed coherently by the capital interests. Therefore, we are in a situation that requires imperatively balance between the interests of the production factors to ensure coherent societal progress. In other words, the capital must be made aware of its effects on it generates, as the situation became critical in some aspects. The impact of production processes on the environment, the destruction of ecosystems or the damage to the flora and fauna of certain regions are irreversible. The economic framework has thus become a profoundly unethical one, a framework in which the immediate profit has prevailed, and the situation is far from reaching a sustainable balance.

In a context in which capital is clearly favoured in all respects, markets - in their capacity to organize - have reacted in the sense of a series of reactions aimed at providing a framework for the conduct of business with societal goals and valences. The phenomenon has definitely been influenced by climate change and its effects on the production processes. The immediate consequences were the emergence of tools intended to ensure ethical behaviour of the capital. These tools are management standards, ways to address production flows or specific marketing tools. Sustainable development, the social economy, the circular economy are conceptual consequences of the situation described above. State intervention was thus premeditated, being deeply involved in financing concepts that ensure ethical behaviour at the capital level. The consequences of the deeply irresponsible behaviour identified in some factors of production have had several adverse consequences, but those concerning human rights, working conditions and the environment are considered to be some of the most important. The rationality of resources, efficiency in production processes, and the sustainability of production processes have become the main pillars of economic debate. Identifying new ways of production and consumption while ensuring the prosperity of citizens and respecting the ecologic limits of the environment have been the ingredients of economic policies at the European level. Social and environmental standards have become, nowadays, ingredients in the absence of which the economic and industrial policies cannot be taken into account. A concrete 
example is the European Union (EU), which is recognized worldwide for the attention given to the environment, strategically and programmatically. The EU currently has one of the most progressive environmental policies. The approach to this issue was in the spirit and levers of capitalism in the sense that the EU saw in this situation a source of economic growth and a competitive advantage with other economies. The structural reorientation of the economies, the modernization of the production processes, the innovation, the facilitation of access to innovation, as well as the identification of new ways of consuming food, products or materials, became concrete in the bioeconomy concept, that is meant to be sustainable and cyclical.

Against a tense Europe, shaken by the economic crisis and also by the global geopolitical situation, the European Commission has launched the Europe 2020 Strategy. It was launched in 2012 as a successor to the Lisbon strategy to generate smart, sustainable and inclusive growth in the EU (Bilas, 2015). The Europe 2020 Strategy became a reference pillar on the EU road towards a development process that directly integrates environmental issues. The Strategy requests the reduction of greenhouse gas emissions by at least $20 \%$ compared to the 1990 levels or by $30 \%$ if there are favourable conditions in this respect increase the share of renewable energies in our final energy consumption by $20 \%$ and increase by $20 \%$ of energy efficiency. Also, achieving the objective of investing in Research and Development $3 \%$ of the GDP, in particular by providing more favourable conditions for the private sector in $R \& D$ investment, and setting a new indicator for innovation, is another goal of the Europe Strategy 2020. The 2014-2020 programming period addresses the issue of the environment in a very direct way, and it is unprecedented from a programmatic point of view. The programming period 2011 - 2027 continues in this line, with the Cohesion Policy already taking on objectives aimed at building a greener and more social EU. The specificity of these objectives is shaped by the thematic allocation proposals managed by Romania in the process of assuring the Presidency of the EU in the first half of 2019. More specifically, the proposals concerning the administration of the budgetary envelope for the period 2021-2027 aim at increasing the thematic allocation from $50 \%$, as it currently stands, at $65 \%$ for the first two thematic objectives. Research, development and innovation benefit from a proposal to allocate $35 \%$ of the total envelope and to reduce $\mathrm{CO} 2$ emissions by a share of $30 \%$. The political and programmatic interest for balanced development and in harmony with the environment is a certain and stable one, which is also present during the next programming period.

The relationship between the environment, social issues and capital, namely businesses, is one that gets more and more attention from stakeholders. National or international protests that concerned the environment or the deterioration of the social situation have intensified over the past two years. The yellow vests, the protests organized by the European Trade Union Confederation, or the movement inspired by the action of Greta Thunberg, a Swedish student who has launched a protest against climate change, are 
Marin, F.

some of the reference movements generated by the stakeholders, movements that directly affect the issues linked with the corporate social responsibility. What is noteworthy is the range of stakeholders involved in such approaches, explicitly mentioning youth and trade union organizations which are becoming more and more concerned with the issue of corporate social responsibility. All these movements are based on a certain issue, namely, dissatisfaction with the degradation of the environment and the general social situation. Moral degradation exerted a much stronger influence, one that contaminates both the economy and society (Messner and Rosenfeld, 1997; Zheng et al., 2014). The rapid economic growth of countries around the world has been achieved at the expense of the huge consumption of environmental and non-renewable resources. Therefore, governments should strengthen their efforts in environmental regulation and should supervise and manage the production behaviour of enterprises in a timely way. Also, enterprises should actively respond to the environmental systems and policies proposed by the government. They should also pursue the goal of sustainable development, take the initiative to undertake social responsibilities, and actively carry out technological innovation and improve processes to reduce pollution and the waste of resources (Guichuan Zhou et al, 2019). Also, the moral degradation of society, the progressive loss of society or the weakening of morality and ethics is a predominant phenomenon that appears in economies, especially in economies in transition (Zheng et al., 2014). In this context, the pressure of the stakeholders has generated a significant change in the way business is organized and run. Businesses had to become concerned with winning and managing the respect of stakeholders and society in general. The concept of corporate social responsibility has been a transformation of corporate culture and policy that incorporates a commitment from companies to contribute to sustainable development and to respect and support human development and human rights, all via dialogue and commitment to the parties interested (Albareda, 2008). The respective sustainable development climate compliance involves difficult processes so that their implementation implies an involvement from all stakeholders as well as a series of innovative solutions that ensure the efficiency of the implementation process. The tools that derive from the employee-employer relationship are little used until now. One of the instruments we refer to is collective agreements, which can contribute to the strengthening of the bioeconomy and implicitly to the sustainability of development.

\section{REVIEW OF SCIENTIFIC LITERATURE - THE STATE OF KNOWLEDGE}

At the end of the '60s, the notion of the environment has integrated several issues in a coherent way, namely pollution, nature conservation and resources. These issues required a scientific assessment but also a comprehensive policy solution (Engels, 2010). Many of the laws that formed an integral part of the 
environmental policy in the 1970s and 1980s were a response to specific conditions, their direct impact is on political and economic nature, not necessarily as part of a visible or systematic strategy for an ecofriendlier community (Hildebrand, 1996). The 1990s were years of reference for the environmental issues at the European level. In 1994, the European Environment Agency was set up, its work being the basis for important directives, adopted at European level. The Packaging and Packaging Waste Directive, the Air Quality Assessment and Management Directive, and the Integrated Pollution Prevention and Control Directive are just a few of the directives approved after the establishment of the above-mentioned agency. Also, in 1997, the Kyoto protocol was signed, setting as its primary objective the reduction of pollutant emissions by $5.2 \%$ in the period 2008-2012, compared to 1990 . The year 2000 is important for the evolution of the Environmental Policy because the Water Framework Directive was approved and laid the foundations of EU waste incineration legislation in order to reduce the pollution of air, water, soil and human health hazards. The European Commission published the Biodiversity Action Plan for the Conservation of Natural Resources in 2001 and endorsed during the Gothenburg Council the Declaration on a European Strategy for Sustainable Development. The EU's concern for the environment has thus become very concrete. In 2004, the Commission launched the Environmental Technologies Action Plan to foster innovation and green industrial development. The enlargement of the EU in 2004 determined the compliance with the legislation having an environmental impact by the new Member States. It should not be neglected the fact that the Reach Regulation on the Control of Industrial Chemicals was formally adopted in 2006.

One of the widely discussed concepts in the last period is bioeconomy. The relevance of bioeconomics has increased considerably in the last period. In recent decades, considerable efforts have been made to promote and ensure sustainable management of natural resources (Fritsche et al., 2014). Environmental issues become a key issue in the development of sustainable development policies, and the development of a bioeconomy strategy by the EU is a clear proof of this. Environmental issues also play an important role in different framework programs or international consortia of the public and private sectors (European Commission, 2012, Mengal, 2018). In all strategic and programmatic documents specific to the 2014-2020 programming period, we identify the 2012 Bioeconomic Strategy, which is then updated in 2018 . The European Bioeconomy includes the production of renewable biological resources and the conversion of these resources and waste streams into value-added, such as food, food for animals, bio-products and bioenergy products. The fundamental principle underpinning the European Bio-Economy Strategy involves balancing social, environmental and economic gains by linking the sustainable use of renewable sources with the protection and restoration of biodiversity, ecosystems and natural capital land and water (European Commission, 2018). In the view of the stakeholders, the strategic bioeconomic framework was lacking practicality. Specifically, the strategic framework lacked clear and measurable objectives, 
environmental objectives or sustainable development. Updating the strategy implied the integration of 14 concrete actions to be launched by 2019 , noting the immediate nature of these actions. These actions have an integrated character, designed to dynamize the bio-economy sector and innovation in the field, being structured in three main directions, as follows: consolidation and expansion of the bioeconomic sectors, unlocking investments and markets; rapid implementation of local bioeconomies across Europe; understanding the ecological limits of the bioeconomy.

Despite the growing EU renewable energy policy, clearly expressed through strategic concerns in the field of bioeconomy, the field is barely in progress in Europe, both in terms of output and jobs that can be created. Bioeconomy should be seen as a niche area or as a concrete opportunity to generate growth and jobs while reducing dependence on fossil fuels, i.e. improving the economic sustainability of primary production and manufacturing (Patricia et al., 2017). The success of a bioeconomy strategy is not confined to technological aspects but includes behavioural change and institutional innovations that allow long-term settings and incentives at both society and enterprise level, at international policy levels (von Braun, 2014). Technical innovation and new business models associated with bioeconomy should aim to decouple economic growth from resource utilization in countries with available resources (Preston and Lehne, 2017). In addition to the strategic approach launched by the European Commission in 2012, Member States have developed their own strategies in this field, thus contributing to providing meaningful information on the structure of these types of activities, their links with the rest of the economy and the capacity to generate wealth and employment of the work force in the context of sustainable development (Gobierno, 2017). At national level, the definition of bioeconomic boundaries is sometimes unclear (European Commission, 2018). Several differences have also been identified from one Member State to another as regards the sectors which form an integral part of the bioeconomy. The sectors included in the bio-economy strategy often reflect the priorities identified by the Member States but also comparative advantages related, for example, to biomass resources, specialized economy, labour productivity and research and development investment (FAO, 2016). The overall objectives of the Member States in the field of bioeconomy include economic growth, employment, energy security, food security, fossil fuel reduction, mitigation and adaptation to climate change and rural development (FAO, 2016).

\section{RESEARCH METHODOLOGY}

The data collection method aimed the collecting collective agreements at company level, in the sectors involving industrial production flows as well as in the bioeconomy specific sectors. 52 collective agreements (32 in the industrial sector, 20 in the bioeconomy sector), which were in force in March 2019, 
were analysed. Collective agreements analysed concern large companies, more than 250 employees in Romania, involved in global production flows, valid for one or two years. Also, public policy documents, legislation and reports on the organization and functioning of social partners with local, regional, national or European action were analysed. The research methodology implied the identification of the thematic synergy between the principles of the ISO 26000 standard, the structure and the elements found in the collective agreements. This assumption implied the individual analysis of each collective agreement in order to classify the clauses identified at their level, according to the ISO 26000 specific principles. The analysis was of a qualitative nature, covering both collective agreements and specific legislation linked to social partners, respectively public policies in the field.

\section{BIOECONOMICS IN THE EUROPEAN UNION (EU)}

Countries can be classified as countries with: (1) abundant renewable bioenergy but lack of downstream processing industries; (2) countries with the potential of feedstock and advanced processing industries; and (3) low feedstock potential, but with advanced processing industries (Axelsson et al, 2012). These variations in potential also generate differences in countries' targets for adopting a bio-economy strategy in the field of bioeconomy and for assessing the potential success or impact on development (Bracco et al., 2018). Eastern European countries have a strong specialization - in terms of both employment and added value - in agriculture and food, beverage and tobacco production, followed by low-productivity sectors (European Commission, 2018). The possibility of producing more biomass from agriculture for different bio-based activities could be significant through the momentum of development for the rural areas of Central and Eastern European countries where, in some regions, subsistence farms dominate, as is Romania at present. A characteristic feature of bio-economy refers to diverse performance from one Member State to another. Following the methodology used by the European Commission to analyse the performance of the bio-economy, we can see that Romania has modest performances compared to the situation at European level. Table 1 presents the dynamics of the bioeconomy performance by analysing the number of employed persons, turnover per person, and the value-added per person.

TABLE 1. THE DYNAMICS OF THE BIO-ECONOMY SITUATION

\begin{tabular}{|c|c|c|c|}
\hline \multicolumn{4}{|c|}{ EU 28 - Euro } \\
\hline Year & Employees & Turnover / person & Value added / person \\
\hline 2008 & 20536545 & 101735 & 28040 \\
\hline 2009 & 19753640 & 95326 & 26585 \\
\hline 2010 & 19614825 & 101698 & 28916 \\
\hline 2011 & 19150576 & 110961 & 30550 \\
\hline
\end{tabular}


Marin, F.

COLLECTIVE AGREEMENT - A TOOL FOR STRENGTHENING PUBLIC POLICIES IN THE AREA OF SOCIAL RESPONSIBILITY

\begin{tabular}{|c|c|c|c|}
\hline Year & Employees & Turnover / person & Value added / person \\
\hline 2012 & 18902689 & 114144 & 30656 \\
\hline 2013 & 18464822 & 119121 & 32050 \\
\hline 2014 & 18369323 & 120878 & 32846 \\
\hline 2015 & 18067648 & 125021 & 34365 \\
\hline \multicolumn{4}{|c|}{ Romania - Euro } \\
\hline 2008 & 3229433 & 11518 & 4335 \\
\hline 2009 & 3152176 & 9267 & 3686 \\
\hline 2010 & 3143144 & 10113 & 3527 \\
\hline 2011 & 2950960 & 12411 & 4298 \\
\hline 2012 & 3009571 & 11074 & 3442 \\
\hline 2013 & 2950486 & 12643 & 4100 \\
\hline 2014 & 2888087 & 12753 & 4048 \\
\hline 2015 & 2625538 & 14082 & 4085 \\
\hline
\end{tabular}

Source: European Commission

Analysing the dynamics of the sectors that are an integral part of the bio-economy at European level, we can see that the number of persons employed within them decreased by 2.468 .896 persons in 2015 compared to 2008, when the turnover increased by 169.532 million euro, and the value added increased by 45.050 million euros. In 2015, over 18 million people were employed in the European bioeconomy, with a turnover of 2.258.826,68 million euros, and an added value of 620.903 million euros. The situation in Romania is atypical, this being generated by the particularities of the Romanian labour market and by the structure of the farms. The number of persons employed in the Romanian bioeconomy was 2.625 .538 in 2015 , a turnover of 36.972 million euros and an added value of 10.725 million euros. We can observe the large number of people employed in the Romanian bioeconomy, but it should be mentioned that these persons are mainly occupied in the subsistence agriculture. As a rule, the economic performance delivered by these people is modest, a situation that is reflected by the turnover per person. In 2008, the EU-28 turnover per person was 101.735 euro, while in Romania it was 11.518 euros $(11.32 \%$ of the EU-28 value). At the same time, in 2015, the turnover per person in EU-28 was 125.021 euros and in Romania the value of the indicator was 14.082 euros (11.26\% of the EU-28 value). The situation is similar in terms of added value in the sense that Romania's performance is modest. In 2008, the value added per person was 28.040 euros at the level of EU-28 and 4.335 euros in Romania. In 2015, the added value per person was 34.365 euro in the EU-28, while in Romania the value of the indicator was 4.085 euro, respectively $11,89 \%$ of the EU-28 value. 
TABLE 2. THE STATE OF BIOECONOMICS BY BRANCH, IN ROMANIA AND THE EU

\begin{tabular}{|c|c|c|}
\hline Branch & $\begin{array}{c}\text { EU 28 } \\
\text { Turnover per employee }(1000 € / / \\
\text { person) }\end{array}$ & $\begin{array}{c}\text { Romania } \\
\text { Turnover per person employed } \\
(1000 € / \text { person })\end{array}$ \\
\hline Agriculture & 41.2 & 6.5 \\
\hline Forestry & 93.0 & 37.4 \\
\hline Fisheries and aquaculture & 52.4 & 8.1 \\
\hline Food, beverages and tobacco & 253.7 & 67.2 \\
\hline Textiles - bio & 103.6 & 17.9 \\
\hline Wood products and furniture & 123.5 & 44.8 \\
\hline Paper & 290.2 & 73.7 \\
\hline $\begin{array}{c}\text { Bio chemicals, pharmaceuticals, } \\
\text { plastics and rubber (except } \\
\text { biofuels) }\end{array}$ & 397.9 & 86.5 \\
\hline Liquid biofuels & 464.1 & 107.6 \\
\hline Electricity - bio & 782.4 & 88.9 \\
\hline
\end{tabular}

Source: European Commission

At the level of EU-28, in 2015, the highest turnover figures are recorded in the bio-based chemical products, pharmaceutical, plastic and rubber sector (excluding bio-fuels), the value of the sector's turnover in 2015 was 397,9 thousand euros. Also, in the agricultural sector there was a value of 41,2 thousandeuro, food and beverages - 253,7 thousand-euro, paper of 290,2 thousand euros, wood and furniture of 123,5 thousand euros. Romania's performance is well below the EU-28 average, which is clearly reflected in the table above. In all sectors that are integral parts of the bio-economy, Romania does not exceed $40 \%$ of the EU average in terms of turnover per employee, the differences being significantly higher. Given that $81,1 \%$ of the persons employed in the agricultural sector in Romania's bio-economy deliver only 37,39\% (13.822.30 million euro), it is more than obvious that we are experiencing low productivity and low performance at sector level. The sector of organic biochemicals, pharmaceuticals, plastics and rubber (excluding biofuels), including Romania, is one of the most performing sectors in terms of yield, which is 86,5 thousand euros, given that the number of employed persons is 13.255 persons, representing $0.5 \%$ of the total number of persons employed in the Romanian bioeconomy. Liquid biofuels have a turnover of 107,6 thousand euro in 2015 , which is $23 \%$ of the European value.

\section{CORPORATE SOCIAL RESPONSIBILITY (CSR)}

Sustainable development has become a widely accepted target for production flows, and the synergy between CSR and the sustainable development has become increasingly prominent. World Business Council for Sustainable Development describes corporate social responsibility as representing an 
Marin, F.

organization's contribution to sustainable economic development on the basis of compliance with regulations and legislation. In other words, it's "the commitment of business environments to contribute to sustainable economic development by working together with the employees, their families, the local community and society as a whole, to improve the quality of their lives." Companies have quickly taken over the CSR, integrating the concept into the organizational management, a process that has catalysed its spreading to markets. Dow Jones Sustainability, the Canadian Jantyi Social Index, Innovest, ISO 26000 are proof of the concerns of investment markets, that are considered to be responsible. Michael E. Porter, a leading authority in the field of competitive strategy, argues in one of his articles that "social responsibility has become a priority impossible to be avoided by business leaders in each country and in any field" (Porter, 2006). By adopting effective CSR ethics programs, companies can benefit from multiple benefits: cost reduction, brand image enhancement, incentives for employees, optimizing opportunities for access to capital, attracting customers and increasing turnover, reducing risks (Hristea, 2011).

The CSR approach aimed, on the one hand, at generating a framework from which organizations could obtain a wide range of benefits from the moment they became long- term employed persons (Du et al., 2010, Sen et al., 2006). CSR organizations are able to attract demand for products from market segments specifically interested in social issues, as consumers tend to focus on products and services of companies considered good corporate citizens (Arli and Lasmono, 2010). Beckmann (2007) adds that consumers take corporate citizenship very seriously into account when deciding to buy a particular product of a company. CSR initiatives not only promote actively businesses that create value (Mackey et al., 2007; Siegel, 2009), but help maintain corporate identity and increase corporate social value (Brickson, 2007). CSR can influence the decision of the quality workforce, especially the labour force for which ethics is a milestone, so employees can look for work within the organization (Sen et al., 2006; Du et al., 2010). Companies will greatly benefit from cost and risk reduction, reputation and competitive advantage will create a profitable situation through their synergy if they engage in CSR (Lindgreen and Swaen, 2010). CSR is considered to be a long-term strategy (Baron, 2001; McWilliams et al., 2002; McWilliams et al., 2006). Elkins (1977) considers CSR as a "protection strategy" to maintain a legitimate society in society. Murray and Montanari (1986) also refer to the strategic importance of CSR, which can be seen as an exchange between a firm and its environment. Nevertheless, hypotheses that CSR performance will exert positive effects on financial performance are partially supported. These results indicate that while CSR activities exert a positive influence on financial performance, not all CSR activities exert statistically significant effects on financial performance (Sang Jun Cho et al, 2019). The relationship between organizational management and CSR has received special attention. Internalizing environmental or social variables has been a trend for companies to address, and these are being addressed in the marketing 
strategy of the businesses. CSR has thus become a way of identifying the needs and expectations of the stakeholders, especially customers, a way of building a good reputation and building trust and credibility. All these are opportune management strategies, but they do not solve the main problem, raised by the CSR, namely the environmental and social issues. Scepticism about CSR is fuelled by the fact that it is not very likely for a company to be concerned about the common good. The only objective that regulates and justifies the company's business is the profit. Moreover, the current situation is clear evidence that CSR is rather a variable of the organizational management and not a real one, a concrete and correct approach to solve environmental or social issues. Corporate Social Responsibility is an emerging critical issue in organizational management (Galan, 2006), one that includes policies and practices that reflect the company's responsibility for a broader social benefit (Matten and Moon, 2008), but these benefits have had an insignificant character compared to the amplitude of the environmental and social problems. Many companies are under the pressure of civil society organizations, monitoring enterprise malpractice (Scherer and Palazzo, 2007). Civil society criticized companies to determine them to adopt and respect decent working conditions everywhere, with fair salaries and social rights protected at international level, by the declarations of the United Nations and the International Labour Organization, the laxity and compliance with national legislation. As far as the environment is concerned, civil society has begun to require companies to respect the $\mathrm{UN}$ and $\mathrm{UN}$-signed conventions and agreements on environment and development and that they take into account basic environmental regulations adopted by Western governments or regional organizations such as the European Commission (Scholte, 2001; Bendell, 2004). In general, CSR activity includes environmental protection, support for a local community, volunteer work, support for developing countries, consumer protection, social benevolence, and diversity. Selecting the right CSR activity from among many possibilities is a very important factor that can improve a company's image and enhance the benefits of its CSR activity (Chang-Hyun and Jung-Yong, 2019).

\section{COLLECTIVE AGREEMENT AND REPRESENTATION OF THE INTEREST OF THE FACTORS OF PRODUCTION}

Given that the right to a healthy environment is an integral part of the law, the foundations for several European countries, the issue of monitoring and controlling the way companies adopt and respect the CSR becomes one of maximum interest for stakeholders in sustainable development. CSR is a problem that derives from the anthology between two factors of production, namely labour and capital, a comparison justified by the structure of the variables found at the level of the CSR. CSR has become a critical aspect of business operations, and this has received considerable momentum in the western 
economies, while in developing economies little or no activity has occurred (Jamali, 2007). Recognizing the full importance of the CSR, many studies discuss its effects, especially in transition economies (Fulop et al., 2000; Wang et al., 2011). With the prevalence of moral degradation of society, CSR implementation becomes more difficult and uncertain in transition economies (Fulop et al., 2000), including Romania. The stakeholders of the CSR have been approached by the majority specialized literature from the point of view of civil society. The relational-identity-oriented organization is very concerned about the relationship maintenance with its immediate stakeholders and tries its best to play a good partner role before those stakeholders. Yet, those stakeholder groups usually have different even conflict interest claims (Yun et al, 2019). One of the most significant implications of globalization is the emergence of non-governmental actors in global governance (Rosenau, 1995, Cutler et al., 1999, Higgott et al., 2000, Hall and Biersteker, 2002). This means that a growing number of global corporations and non-governmental organizations seem to have taken a political role in the global political economy (Cutler et al., 1999; Hall and Biersteker, 2002). Also, entities that form an integral part of civil society are mainly represented by NGOs, these types of organizations being the most vocal types of entities in relation to specific CSR themes, especially those related to the environment. The degradation of the environment and the social situation is a process far from being dimmed, hence the fact that the effectiveness of NGOs in managing or counteracting this phenomenon is a limited and limited one, which is much smaller than the actual amplitude of the problem. Efforts have been made by the political environment, a concrete example being the European directives that ensure the disclosure of non-financial information by companies. In the EU, CSR is recognized and supported both by legal provisions generated by the EU and EU member states and by the actions of all stakeholders, especially companies. Nevertheless, there are many questions and issues linked to the determination of the exact dimension of the mandatory features of the legal duty to provide CSR information, and in particular in annual reports and the e-publication of these annual reports (Radka, 2019). Romania has transposed this directive into the national legislation, but only the mere publication of this information cannot generate real progress. The efficiency of such an approach is expected to be small because the entire control over the strategic directions adopted or the sums allocated to CSR lies with the company. In the absence of an instrument to ensure a check-and-balance check, simply publishing data on CSR strategies provides at most another variable to strengthen the company's marketing, and not a substantive solution that is so necessary given the current conditions. Empowering companies is a tricky, permanently dimmed struggle for survival and competition. The efficiency and effectiveness of such an approach is given by organizational tools that have direct and permanent action on companies, implicitly with the business environment. Entities managing the relationship between labour and capital are the social partners. The organizational structure, the legislation and the non-legislative measures that regulate 
this relationship allow for a sustained contact with the companies, respectively with the global production flows.

The social partners are an institutional expression of the representation of the interest of the production factors, namely the labour unions and the employers' associations for the capital. The organization of the social partners - the signatories to the collective agreements - provides a multi-level approach to CSR and bio-economy issues. Codecision is a basic principle in the model of European social dialogue, a transversal principle found in specific legislation or even in dedicated institutions, the Economic and Social Council being clear evidence in this respect.

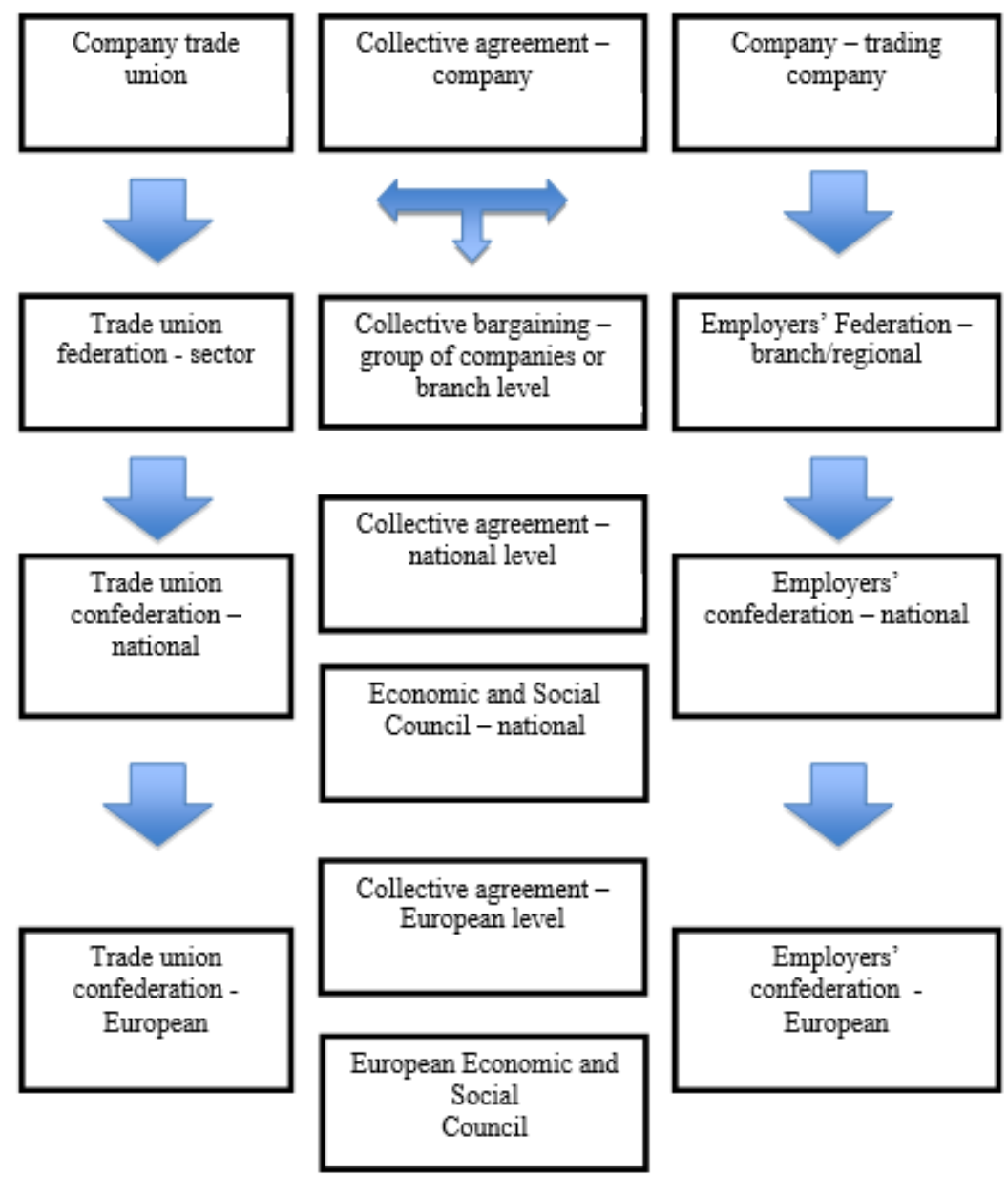

FIGURE 1. ORGANIZING SOCIAL PARTNERS

Source: Own data processing

The concrete interaction of the two factors of production is the collective agreement. According to the legislation it can take several forms, depending on the level of applicability, respectively at company level, 
Marin, F.

at the level of group of units, national, European or even global. The collective agreement is the institution that can provide a framework for negotiating, monitoring and controlling the features and modalities of CSR implementation. Also, the collective agreement can ensure the transfer of classical production flows to bioeconomic. The collective agreement is a voluntary agreement with a non-legislative measure that generates immediate legal consequences as well as a series of responsibilities that can be sanctioned in court on the basis of the procedural quality of the parties. The collective agreement, whether we refer to the one applicable at company, sector, group, or national level, can be a superior tool for monitoring and controlling CSR implementation, primarily because it ensures firm commitment from companies. The effectiveness of such an instrument depends to a large extent on the ability of the social partners to turn collective agreements into instruments that identify with CSR issues and the bio-economy. The way of organizing the social partners, the organizational and institutional structure, and also the synergy with CSR provisions are elements that can catalyse the efficiency of the process of adoption, monitoring, control and implementation of CSR strategies. Specifically, democracy, the interest of the social partners and civil society, is institutionalized internally, the institution referred to by the Economic and Social Council (ESC), which is found at both Member State and European (EESC) levels. The environment issue is the subject of the agenda of the European ETUC, with a concrete example being France, which has made its statement, including its name, namely Conseil Économique, Social et Environnemental. The existence of such an institution is an institutionalized proof of the synergy of the social partners' interests with the environmental issue, and in particular with the responsibility of companies in general.

The opportunity to use collective agreements as a solution to streamline CSR and reorient production flows to the bio-economy sector is emphasized by the thematic exposure of collective agreements to specific CSR and bioeconomy issues. In order to analyse this issue, we analysed the synergy between the provisions of the collective agreements, and the ISO 26000 principles. 


\begin{tabular}{|c|c|c|c|}
\hline Clause name & Sector & Bioeconomy & ISO 26000 \\
\hline $\begin{array}{c}\text { Prevention of risks both } \\
\text { inside and outside the } \\
\text { facility }\end{array}$ & $\checkmark$ & $\checkmark$ & $\checkmark$ \\
\hline $\begin{array}{c}\text { Protection of the } \\
\text { environment - specific } \\
\text { clauses }\end{array}$ & $\checkmark$ & & $\checkmark$ \\
\hline $\begin{array}{c}\text { Relationship with the } \\
\text { community }\end{array}$ & $\checkmark$ & $\checkmark$ & $\checkmark$ \\
\hline Social Involvement & $\checkmark$ & $\checkmark$ \\
\hline $\begin{array}{c}\text { Code of Conduct / } \\
\text { Ethical Code }\end{array}$ & $\checkmark$ & $\checkmark$ & $\checkmark$ \\
\hline
\end{tabular}

Source: our own data processing

All collective agreements analysed directly affect the social variable, which is treated at the level of employees as well as at the level of other people such as their families or community members. Social protection of employees is a variable with a wide spread at the level of the contracts analysed. Vocational training is the subject of collective agreements, but it does not specify in a clear manner what the training fields are, whether they are oriented towards employees' competitiveness or awareness of certain issues, such as those that concern environmental protection. All 52 contracts analysed deal with social issues, a situation that ensures a well-established applicability of this instrument in social issues at the level of companies. Environmental issues are addressed mainly through health and safety at work, a situation found in all 52 contracts analysed. Risk prevention is a matter of direct concern to the environment, which is addressed in all the contracts analysed. Environmental protection is found in collective agreements or in adjacent documents (regulations, codes, etc.) at the level of all collective agreements in companies with industrial production flows outside the bio-economy sector. Relationship with the community and social involvement are integrated into collective agreements but it is specific to companies with over 1.000 employees, large companies. Also, the relationship with the community is found to be integrated mainly in the documents adjacent to the collective agreement. The situation is roughly similar in the case of ethical codes, which are found in the adjacent documents. The Code of Ethics is invoked under collective agreements and forms an integral part thereof.

Analysing the synergy of collective agreement clauses with ISO 26000, we can see a considerable synergy demonstrated by the above table. Thematic synergy is much greater for industrial companies that target production flows with an impact on the environment. However, no collective agreements have been identified that benefit from a chapter dedicated to the CSR. If the industrial sector has a significant synergy with ISO 26000, the bio-economy sector only affects social issues by assuming that the entire activity of the companies in the sector is environmentally friendly. The justification for this assertion is that the 
bioeconomy sector is predominantly populated by companies with lower capacity compared to the industrial sector, which is still in the beginning in Romania. Also, none of the 52 contracts explicitly mention CSR strategy and does not relate to published non-financial data. At this time, the collective agreement provides a consistent thematic exposure, but is seen as a stand-alone instrument although it has all the qualities and specifics of an instrument within the CSR.

\section{CONCLUSIONS}

The interest of the European Commission for CSR and bioeconomy is clearly proven by the legislative and strategic framework approved in the last 7 years. The approach of environmental issues has been done in line with the principles of capitalism, more precisely in the direction of increasing economic competitiveness. The structural shift in production flows towards a responsible and sustainable model is a difficult process under the conditions of consistent competition. Bioeconomy is a declared objective at EU level. The existence of a strategic and financing framework, such as the Bioeconomy Strategy, catalyses the process of reorientation of classical production flows into one according to the principles of bioeconomy. Nevertheless, bioeconomy is in its early stages in Europe, the turnover achieved in the sector, the created jobs and the added value achieved clearly reveal this. Romania is below the EU average in terms of turnover or value added in the bioeconomy sector. In Romania, the bioeconomy sector is dominated by 3 sectors, namely agriculture, food and tobacco, and wood and furniture. These cover over $80 \%$ of turnover and over $85 \%$ of employees.

The catalysing of the bioeconomy depends largely on the efficiency and effectiveness of the CSR. Although it has benefited from a major exposure lately by a wide range of stakeholders, CSR issues are rather a marketing approach that supports the development and consolidation of the company, not a solution to the issue of environmental degradation or social situation. Legislation on the obligation to publish non-financial data cannot be a realistic solution, although it is a breakthrough in the field. Currently, there is only a requirement for the publication of non-financial data, without control over the real impact of this approach. The lack of concrete control that can penalize the company with regard to the effectiveness or utility of implemented CSR approaches justifies the need for tools much more adapted to the specifics of industrial relations, respectively to current economic and social realities. The collective agreement is the tool that can deliver a solution to the CSR problem and could contribute to strengthening the bioeconomy. It has a specific character, it is in line with the principles of capitalism, generates legal effects, represents a willingness agreement from the entities representing the interest of CSR stakeholders, and does not involve state intervention, allowing the market to adjust itself. Thematic concentration, control, financial 
commitments and monitoring are imperative ingredients, necessary for CSR efficiency that can be transferred to collective agreements. The organizational and operational modalities specific for the representation entities of the production factors of capital and labour allow the use of collective agreements at company, regional, national or European level. The analysis of the thematic synergy with CSR principles, using the ISO 26000 standard, highlighted a consistent synergy in terms of both the environmental and social variables. The collective bargaining institution is the tool perfectly suited to the CSR issue that has the capacity to strengthen the bioeconomy sector through a specific involvement and the assumption of these principles by the social partners.

Collective bargaining can help ensure a process of structural reorientation of the economy, thus providing the necessary levers for such a process. European business committees, policy bodies at the level of European multinational companies, integration of the CSR strategy into the company's purchasing policy, development of standards and labels at branch or national level, which can be further integrated into company policy documents represent some of the results linked to the use of collective agreements to ensure the effectiveness of the CSR. The use of collective bargaining tools is a fully resonant approach to capitalist principles, with the market being able to regulate itself and the state not having a role in the whole process. In some branches that are found in the Romanian bioeconomy, such as the textile one, the collective agreement tool is already functional, using as benchmark the production flow. For example, multinational companies select their subcontractors after a collective agreement check and after a discussion with the union to ensure the validity of those found in the collective agreement. In relation to bioeconomy and CSR, the collective agreement is an organizational innovation that generates a new business model, a model in which the social partners are involved in the structural shift of production flows, into an environment - friendly process, both sustainable and responsible.

\section{REFERENCES}

Albareda L. (2008). Corporate responsibility, governance and accountability: from self-regulation to coregulation, Corporate governance, accountability and mechanisms of accountability: an overview. Accountability Journal, 21(7): 885-906.

Arli, D.I. \& Lasmono, H.K. (2010). Consumers' perception of corporate social responsibility in a developing country. International Journal of Consumer Studies, 34(1): 46-51.

Axelsson, L., Franzén, M., Ostwald, M., Berndes, G., Lakshmi, G. \& Ravindranath, N.H. (2012). Perspective: Jatropha cultivation in southern India: Assessing farmers' experiences. Biofuels Bioprod. Biorefin, 6, 246-256.

Baron, D. (2001). Private politics, corporate social responsibility and integrated strategy. Journal of Economics\& Management Strategy, 10(1): 7-45.

Beckmann, S. (2007). Consumers and corporate social responsibility. Australasia Marketing Journal. 15(1), 27-36. 
Bendell, J. (2004). Barricades and boardrooms: a contemporary history of the corporate accountability movement. Technology, Business and Society, Programme Paper. No. 13. UNRISD, Geneva.

Bilas, V. (2015). The Lisbon Strategy lessons: perspectives of the europe 2020 implementation. 9th International Scientific Conference "Economic and Social Development". Istanbul, 9-10 April 2015.

Bracco, S., Calicioglu, O., Gomez San Juan, M., \& Flammini, A. (2018). Assessing the contribution of bioeconomy to the total economy: A review of national frameworks. Sustainability, 10(6), 1698.

Brickson, S.L. (2007). Organizational identity orientation: the genesis of the role of the firm and distinct forms of social value. Academy of Management Review, 32(3), 864-888.

Chang-Hyun J. \& Jung-Yong L. (2019). The Halo Effect of CSR Activity: Types of CSR Activity and Negative Information Effects. Sustainability, 11(7), 2067.

Cutler, A.C., Haufler, V. \& Porter, T. (1999). Private Authority and International Affairs. New York State University Press, New York, 1999, NY.

Du, S., Bhattacharya, C.B. \& Sen, S. (2010). Maximising business returns to corporate social responsibility (CSR): the role of CSR communication. International Journal of Management Reviews, 12(1), 8-19.

Elkins, A. (1977). Toward a positive theory of corporate social involvement. Academy of Management, 2(1), 128-133.

Engels, J.I. (2010). Modern Environmentalism, in: Uekötter, Frank (ed.): The Turning Points of Environmental History. Pittsburgh: 19-131.

European Commission. (2012). Innovating for Sustainable Growth: A Bioeconomy for Europe.

European Commission. (2018). Bioeconomy Knowledge Centre. Bioeconomy Data Catalogue.

European Commission. (2018). Roadmap. Update of the 2012 Bioeconomy Strategy; European Commission: 3.

Food and Agriculture Organization of United Nations (FAO). (2016). How Sustainability Is Addressed in Official Bioeconomy Strategies at International, National, and Regional Leveles-An Overview. Food and Agriculture, Organization of United Nations: Rome, Italy.

Fritsche, U. R., \& Iriarte, L. (2014). Sustainability criteria and indicators for the bio-based economy in Europe: State of discussion and way forward. Energies, 7(11), 6825-6836.

Fulop, G., Hisrich, R. \& Szegedi, K. (2000). Business ethics and social responsibility in transition economies. Journal of Management Development, 19(1), 5-31.

Galan, J.I. (2006). Corporate social responsibility and strategic management. Journal of Management Studies, 43(7), 1629-1641.

Gobierno de España. (2016). Ministry of Economy and Competitiveness. The Spanish Bioeconomy Strategy 2030 Horizon.

Guichuan Z., Lan Z. \& Liming Z. (2019). Corporate Social Responsibility, the Atmospheric Environment, and Technological Innovation Investment. Sustainability, 11(2), 481.

Hall, R.B. \& Biersteker, T.J. (2002). The Emergence of Private Authority in Global Governance. Cambridge University Press, Cambridge. 2002.

Higgott, R., Underhill, G.R.D. \& Bieler, A. (2000). Globalisation and non-state actors, in Higgott, R., Underhill, G.R.D. \& Bieler, A. (Eds), Non-state Actors and Authority in the Global System, Routledge, London, 2000.

Hildebrand P.M. (1996). The European Community's Environmental Policy, 1957 to '1992': From Incidental Measures to an International Regime? Environmental Politics, 1, 13-44. 
Hristea A. (2011). Responsabilitatea socială corporativă - între deziderat şi realitate. Economie teoretică şi aplicată. XVIII ,10(563), 56-73.

Jamali, D. (2007). The case for strategic corporate social responsibility in developing countries. Business \& Society Review, 112(1), 1-27.

Lindgreen, A. \& Swaen, V. (2010). Corporate social responsibility. International Journal of Management Reviews, 12(1), 1-7.

Mackey, A., Mackey, T.B. \& Barney, J.B. (2007). Corporate social responsibility and firm performance: investor relations and corporate strategies. Academy of Management Review, 32(3), 817-835.

Matten, D. \& Moon, J. (2008). 'Implicit' and 'explicit' CSR: a conceptual framework for a comparative understanding of corporate social responsibility. Academy of Management Review, 33(2), 404-424.

McWilliams, A., Siegel, D.S. \& Wright, P.M. (2006). Corporate social responsibility: strategic implications. Journal of Management Studies, 43(1), 1-18.

McWilliams, A., Van Fleet, D.D. \& Cory, K. (2002). Raising rivals' costs through political strategy: an extension of the resource-based theory. Journal of Management Studies, 39(5), 707-724.

Mengal, P., Wubbolts, M., Zika, E., Ruiz, A., Brigitta, D., Pieniadz, A. \& Black, S. (2018). Bio-based Industries Joint Undertaking: The catalyst for sustainable bio-based economic growth in Europe. New Biotechnol, 40, 31-39.

Messner, S. \& Rosenfeld, R. (1997). Political restraint of the market and levels of criminal homicide: a cross-national application of institutional-anomie theory. Social Forces, 75(4), 1393-1416.

Murray, K.B. \& Montanari, J.B. (1986). Strategic management of the socially responsible firm: integrating management and marketing theory. Academy of Management Review, 11(4): 815-827.

Patricia, D., Fuentes-Saguar, I.D., Alfredo, J., Mainar-Causapé \& Emanuele Ferrari. (2017). The Role of Bioeconomy Sectors and Natural Resources in EU Economies: A Social Accounting Matrix-Based Analysis. Sustainability, 9(12).

Porter, Michael E. \& Kramer, Mark R. (2006). Strategy \& Society - The Link Between Competitive Advantage and Corporate Social Responsibility. Harvard Business Review, 4.

Preston, F. \& Lehne, J. (2017). A Wider Circle? The Circular Economy in Developing Countries; Chatham House. The Royal Institute of International Affairs: London, UK.

Radka, MacGregor, Pelikánová. (2019). Corporate Social Responsibility Information in Annual Reports in the EU-A Czech Case Study. Sustainability, 11(1), 237.

Rosenau, J.N. (1995). Governance in the twenty-first century. Global Governance, 1, 13-43.

Sang, J.C., Chune, Y.C. \& Jason, Y. (2019). Study on the Relationship between CSR and Financial Performance. Sustainability, 11(2), 343.

Scherer, A.G. \& Palazzo, G. (2007). Toward a political conception of corporate responsibility: business and society seen from a Habermasian perspective. Academy of Management Review, 32(4), 10961120.

Scholte, J.A. (2001). Globalisation, governance and corporate citizenship. Journal of Corporate Citizenship, 1, 15-23.

Sen, S., Bhattacharya, C.B. \& Korschun, D. (2006). The role of corporate social responsibility in strengthening multiple stakeholder relationships: a field experiment. Journal of the Academy of Marketing Science, 34(2), 158-166.

Siegel, D.S. (2009). Green management matters only if it yields more green: an economic/strategic perspective. Academy of Management Perspectives, 23(3), 5-16.

von Braun, J. (2014). Bioeconomy and sustainable development—Dimensions. Rural, 21, 6-9. 
Marin, F.

COLLECTIVE AGREEMENT - A TOOL FOR STRENGTHENING PUBLIC POLICIES IN THE AREA OF SOCIAL RESPONSIBILITY

Wang, M., Qiu, C. \& Kong, D. (2011). Corporate social responsibility, investor behaviors, and stock market returns: evidence from a natural experiment in China. Journal of Business Ethics, 101(1), 127-141.

Yun, L., Greg, G.W. \& Yu, C. (2019). Why Are Corporations Willing to Take on Public CSR? An Organizational Traits Approach. Sustainability, 11(2), 524.

Zheng, Q., Luo, Y. \& Wang, L. (2014). Moral degradation, business ethics, and corporate social responsibility in a transitional economy. Journal of Business Ethics, 120(3), 405-421. 